Article

\title{
Microstructure and Mechanical Properties of an Austenitic CrMnNiMoN Spring Steel Strip with a Reduced Ni Content
}

\author{
Christina Schröder *, Marco Wendler, Olena Volkova and Andreas Weiß \\ Institute of Iron and Steel Technology, TU Bergakademie Freiberg (TU BAF), 09596 Freiberg, Germany; \\ marco.wendler@iest.tu-freiberg.de (M.W.); volkova@iest.tu-freiberg.de (O.V.); weiss@iest.tu-freiberg.de (A.W.) \\ * Correspondence: Christina.Schroeder@iest.tu-freiberg.de
}

Received: 17 April 2020; Accepted: 9 May 2020; Published: 12 May 2020

check for updates

\begin{abstract}
The article presents the mechanical properties of the austenitic stainless steel X5CrMnNiMoN16-4-4 after deformation by cold rolling and subsequent short-term tempering (deformation and partitioning (D\&P) treatment). Tensile strengths of 1700-900 MPa and beyond were achieved both after work hardening and in the D\&P-treated strip. The initial state of austenite in terms of grain size and pre-strengthening, as well as the selected cold rolling temperature significantly influenced the deformation-induced formation of $\alpha^{\prime}$ martensite and thus the flow and hardening behavior of the steel. The usage of two different rolling temperature regimes showed that the strength properties in the cold strip can be specifically adjusted. Lower deformation-induced martensite fractions enabled a larger thickness reduction of the strip without increasing the rolling force, while high deformation-induced martensite fractions led to strong hardening at low deformation levels. The D\&P-treatment permits the strength of the cold-rolled strip with a predominantly austenitic microstructure to be increased to the required level. The total elongation of such a D\&P strip was well over $2 \%$. The D\&P treatment of the spring steel strip is a cost-effective alternative to conventional tempering treatment.
\end{abstract}

Keywords: austenitic stainless spring steel; CrMnNi-steel; deformation-induced $\alpha^{\prime}$ martensite; TRIP/TWIP effect; deformation and partitioning treatment; D\&P

\section{Introduction}

Spring steels are metastable austenitic steels with martensite start $\left(\mathrm{M}_{\mathrm{s}}{ }^{\prime}\right)$ temperatures near and below room temperature (RT) after solution annealing. The required high strength is achieved by creating a mainly martensitic microstructure through appropriate cold forming and subsequent tempering. As a result of tempering, carbide precipitates are preferentially formed in the martensite and residual stresses are relieved [1-3]. The tolerance of the $\delta$-ferrite fraction is $2 \mathrm{vol} \%$. Stainless spring steels are classified as corrosion-resistant steels due to their chromium content exceeding $12 \mathrm{wt} \%$. Additions of molybdenum and nitrogen improve the corrosion properties and increase the resistance to pitting corrosion [4].

As springs are stressed in the elastic region, high demands are placed on the elastic limit and tensile strength of spring steel, while low demands are placed on the toughness. In the work-hardened condition $+\mathrm{C} 1700$, for example, tensile strengths of 1700 to $1900 \mathrm{MPa}$ at total elongations of $\geq 2 \%$ are required for 0.2-mm-thick spring steel strips made of the most commonly used spring steel 1.4310 (X10CrNi18-8; AISI 301). When stainless steel springs are exposed to a corrosive environment, they must meet special corrosion requirements depending on the application.

The cost-effective production of high-strength spring steel strip depends mainly on the type of spring steel and its alloy content. In this context, to what extent the nickel content of conventional spring 
steels can be reduced and partially replaced by manganese and nitrogen must be examined. In contrast to nickel, nitrogen increases the strength strongly $[5,6]$. In recent years, extensive research, including studies in the CRC 799 "TRIP-Matrix-Composite", have shown that reduced nickel contents reduce the austenite stability and thus promote the formation of $\alpha^{\prime}$ martensite [7-9]. Increasing nitrogen and manganese contents increase the austenite stability and reduce the formation of $\alpha^{\prime}$ martensite $[10,11]$. This is expressed, for example, by the corresponding effective factors in the calculation of martensitic transformation temperatures or the nickel equivalent in the Schaeffler diagram [12-15].

The alloying concept has already been presented and the forming conditions for the production of a cold-rolled strip described using laboratory alloys with graded Mn contents [16-18]. In the present study, the austenitic steel X5CrMnNiMoN16-4-4 was selected for the production of a spring strip with a tensile strength of 1700-1900 MPa. The steel possesses reduced the nickel content by approximately $48 \%$ compared to the conventional stainless spring steel 1.4310 .

Our own research results have shown that the transformation-induced and twinning-induced plasticity (TRIP/TWIP) can be technically used to improve the cold forming behavior of austenitic CrMnNi steels [7,19-21]. The increase in plasticity can be used to achieve higher thickness reductions during the cold rolling of strips within a cold rolling stage before intermediate annealing. This offers the potential to reduce the necessary number of intermediate annealing during cold forming. The determination of the final cold forming conditions is of decisive importance for the production of spring strips. The results discussed in [7] concerning the TRIP/TWIP behavior were determined by tensile tests on solution-annealed round specimens with an austenitic microstructure. Deviations from these results are to be expected for annealed austenitic cold-rolled strips if they are subjected to cold rolling, since the $\alpha^{\prime}$ martensite formation under tensile and compressive stress behaves differently. Under comparable forming conditions, the formation of $\alpha^{\prime}$ martensite is less favored under compressive stress than under tensile stress [22]. In addition, however, a large number of shear systems can contribute to the formation of $\alpha^{\prime}$ martensite under multi-axial loading [2,23]. The aim of the work was to adjust the required spring band strength under multi-axial compressive stress during cold rolling.

A spring strip with a predominantly martensitic microstructure is usually tempered to improve the combination of a high tensile strength and still sufficient toughness [24]. Short-term heat treatment, as carried out for martensitic steels according to the quenching and partitioning treatment [25], is excluded for stainless austenitic spring steel strips. To what extent, however, the tensile strength of work-hardened strips can be increased by a final deformation and partitioning (D\&P) treatment must be clarified. In this case, the $\alpha^{\prime}$ martensite required for strength is formed by deformation, i.e., by cold forming. The subsequent short-term heat treatment enables the interstitial alloying elements $C$ and $\mathrm{N}$ to diffuse from the supersaturated martensite $[25,26]$. The diffusion processes can be accelerated due to the high dislocation density, as is the case during forming, for example, during cold rolling. The D\&P treatment leads to the formation of nanometre-sized precipitates in $\alpha^{\prime}$ martensite [27]. This is accompanied by precipitation hardening, which causes an increase in the strength and counteracts the recovery effects [3]. In addition, carbon and nitrogen accumulate at the austenite/martensite phase boundaries as a result of diffusion (partitioning). Consequently, the austenite is stabilized.

\section{Materials and Methods}

Table 1 shows the chemical composition of the steel X5CrMnNiMoN16-4-4 with the abbreviation $4 \mathrm{Mn}$. In addition, the table gives the nickel and chromium equivalent, the $\mathrm{M}_{\mathrm{s}}{ }^{\alpha^{\prime}}$ temperature (1) calculated according to the Eichelmann and Hull relationship [12], and the stacking fault energy $\gamma_{\mathrm{SF}}$ (2) calculated according to Dai et al. [28]. The spring steel $4 \mathrm{Mn}$ is alloyed with molybdenum and exhibits an increased nitrogen and manganese content with a significantly lower nickel content than the conventional spring steel 1.4310 (X10CrNi18-8; AISI 301). The expensive alloying element nickel was reduced by approximately $48 \%$. If the chromium and nickel equivalents are plotted in the Schaeffler diagram, it can be seen that the steel has an metastable austenitic structure [16]. 
Microstructural investigations and magnetic measurements confirm that the steel exhibits an austenitic microstructure with ferrite fractions of approximately 1 to $3 \mathrm{vol} \%$ in the cast state at RT. The $\delta$-ferrite fraction decreases to $\leq 1 \mathrm{vol} \%$ after forging. Approximately $1 \mathrm{vol} \%$ as-quenched $\alpha^{\prime}$ martensite could be detected after liquid nitrogen treatment. The stacking fault energy of $<40 \mathrm{~mJ} / \mathrm{m}^{2}$ indicates that in the case of an external load, e.g., under cold rolling, deformation-induced twin formation and/or deformation-induced $\alpha^{\prime}$ martensite formation can occur in the austenite.

$$
\begin{aligned}
\mathrm{M}_{\mathrm{s}}{ }^{\alpha^{\prime}}\left[{ }^{\circ} \mathrm{C}\right]= & 1305-1665 \cdot(\mathrm{wt}-\% \mathrm{C}+\mathrm{wt}-\% \mathrm{~N})-28 \cdot \mathrm{wt}-\% \mathrm{Si}-33 \cdot \mathrm{wt}-\% \mathrm{Mn}-42 \cdot \mathrm{wt}- \\
& \% \mathrm{Cr}-61 \cdot \mathrm{wt}-\% \mathrm{Ni} \\
\gamma_{\mathrm{SF}}\left[\mathrm{mJ} / \mathrm{m}^{2}\right]= & 39+1.59 \cdot \mathrm{wt}-\% \mathrm{Ni}-1.34 \cdot \mathrm{wt}-\% \mathrm{Mn}+0.06 \cdot(\mathrm{wt}-\% \mathrm{Mn})^{2}-1.75 \cdot \mathrm{wt}-\% \mathrm{Cr} \\
& +0.01 \cdot(\mathrm{wt}-\% \mathrm{Cr})^{2}+15.21 \cdot \mathrm{wt}-\% \mathrm{Mo}-5.59 \cdot \mathrm{wt}-\% \mathrm{Si}+26.27 \cdot(\mathrm{wt}-\% \mathrm{C} \\
& +1.2 \cdot \mathrm{wt}-\% \mathrm{~N}) \cdot(\mathrm{wt}-\% \mathrm{Cr}+\mathrm{wt}-\% \mathrm{Mn}+\mathrm{wt}-\% \mathrm{Mo})^{1 / 2}+0.61 \cdot[\mathrm{wt}-\% \mathrm{Ni} \cdot \\
& (\mathrm{wt}-\% \mathrm{Cr}+\mathrm{wt}-\% \mathrm{Mn})]^{1 / 2}-60.69 \cdot(\mathrm{wt}-\% \mathrm{C}+1.2 \cdot \mathrm{wt}-\% \mathrm{~N})^{1 / 2}
\end{aligned}
$$

Table 1. Chemical analysis of the laboratory steel $4 \mathrm{Mn}$ in wt\% with the calculated values of nickel and chromium equivalents $\left(\mathrm{Ni}_{\mathrm{eq}} ; \mathrm{Cr}_{\mathrm{eq}}\right)$, of $\mathrm{M}_{\mathrm{s}}{ }^{\alpha^{\prime}}$ temperature and stacking fault energy $\left(\gamma_{\mathrm{SF}}\right)$.

\begin{tabular}{cccccccccccc}
\hline Steel & $\mathrm{Cr}$ & $\mathbf{M n}$ & $\mathrm{Ni}$ & $\mathrm{Si}$ & $\mathbf{C}$ & $\mathbf{N}$ & $\mathbf{M o}$ & $\begin{array}{c}\mathbf{N i}_{\text {eq }} \\
{[-]}\end{array}$ & $\begin{array}{c}\mathrm{Cr}_{\text {eq }} \\
{[-]}\end{array}$ & $\begin{array}{c}\mathbf{M}_{\mathbf{s}} \boldsymbol{\alpha}^{\prime} \\
{\left[{ }^{\circ} \mathbf{C}\right]}\end{array}$ & $\begin{array}{c}\gamma \mathrm{SF} \\
{\left[\mathbf{m J} / \mathbf{m}^{2}\right]}\end{array}$ \\
\hline $4 \mathrm{Mn}$ & 16.50 & 4.02 & 4.08 & 0.33 & 0.05 & 0.18 & 0.59 & 10.9 & 17.6 & -165 & 28.6 \\
\hline
\end{tabular}

The austenitic steel $4 \mathrm{Mn}$ was produced under laboratory conditions, hot-rolled into a strip with a thickness of $3.5 \mathrm{~mm}[16,17]$, and then cold-rolled to different strip thicknesses with a number of forming steps in only one cold rolling stage without intermediate annealing. The cold rolling tests were carried out on a dual rolling mill with rolls of an approximately 250-mm diameter. Two different cold rolling strategies were carried out: The first series involved a constant initial temperature of $40{ }^{\circ} \mathrm{C}$ before each roll pass. In the second series, the first rolling step was performed at $40^{\circ} \mathrm{C}$ and the generated heat during rolling was used for subsequent rolling steps. Thus, the rolling temperature in the following passes was between 80 and $110^{\circ} \mathrm{C}$. In both rolling strategies, the degrees of deformation in the individual rolling passes were $0.18 \pm 0.03$. The maximum deformation was limited by the available maximum rolling force of the rolling mill. No intermediate annealing was carried out between the forming passes. The reverse transformation start and finish temperatures of martensite to austenite $\left(\mathrm{A}_{\mathrm{s}}=549 \pm 2{ }^{\circ} \mathrm{C}\right.$ and $\mathrm{A}_{\mathrm{f}}=618 \pm 10^{\circ} \mathrm{C}$ ) were determined from dilatation curves obtained during the heating of the cold-rolled sheet after a degree of deformation of 0.85 and with a deformation-induced martensite content of $57 \%$. Work-hardened samples of the first and second cold rolling series were subjected to an annealing treatment below the reverse transformation temperature at 450,500, and $550{ }^{\circ} \mathrm{C}$ for $5 \mathrm{~min}$ in a salt bath and subsequently quenched in water.

Some cold-rolled 1.8-mm-thick samples were heat-treated at $1050{ }^{\circ} \mathrm{C}$ for $10 \mathrm{~min}$ and quenched to room temperature (RT) by nitrogen gas to investigate the microstructure and mechanical properties after solution annealing.

The microstructures were characterized by light optical and scanning electron microscopy (SEM) (Zeiss NTS GmbH, Oberkochen, Germany) using electrolytically polished and etched hot strip and cold strip samples. The average austenite grain size was determined using the EBSD/SEM (OIM XM4, Edax-Ametek inc., New Jersey, USA), and the remaining $\delta$ ferrite could be detected in the hot-rolled and annealed samples. In addition, $\alpha^{\prime}$ martensite was detected in samples with different work-hardening properties. The quantitative determination of the deformation-induced $\alpha^{\prime}$ martensite fraction as well as of $\delta$ ferrite was carried out using the magnetic measuring device MSAT (Metis I\&E $\mathrm{NV}$, Leuven, Belgium) equipped by a Lake Shore fluxmeter.

The mechanical properties were determined using flat tensile specimens with dimensions based on DIN 50125-H12.5x50 parallel to the rolling direction at RT. The tests were carried out on a universal 
testing machine Inspekt 200 (Hegewald \& Peschke Meß- und Prüftechnik GmbH, Nossen, Germany) with extensometer.

\section{Results and Discussion}

\subsection{Microstructure and Mechanical Properties of Hot Strip and Solution Annealed Cold Strip}

Figure 1a shows the predominantly austenitic structure of the 3.5-mm hot-rolled strip. The austenite is characterized by a fine-grained structure with an average grain size of $9 \pm 5 \mu \mathrm{m}$ (grain size number $\mathrm{G}=10$, ASTM E112). Figure $1 \mathrm{~b}$ presents the austenitic structure of the solution-annealed 1.8-mm cold-rolled strip. In contrast to the hot strip, the solution-annealed cold strip has a coarser austenitic microstructure at RT. The average austenite grain size increased four times to $36 \pm 23 \mu \mathrm{m}$ $\left(\mathrm{G}=6\right.$; ASTM) during annealing. Isolated coarse acicular $\alpha^{\prime}$ martensite was observed on the sample surface. This preparation-induced martensite was formed due to grinding and polishing operations. Such behavior indicates the low stability of the austenite.

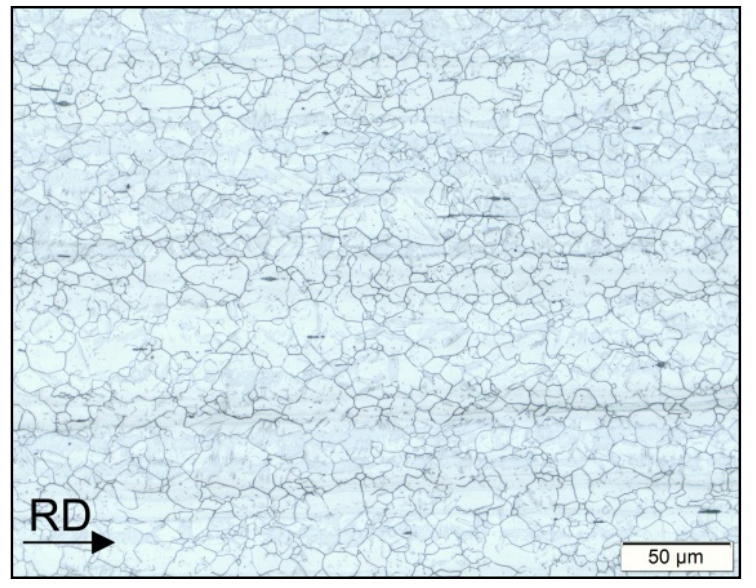

(a)

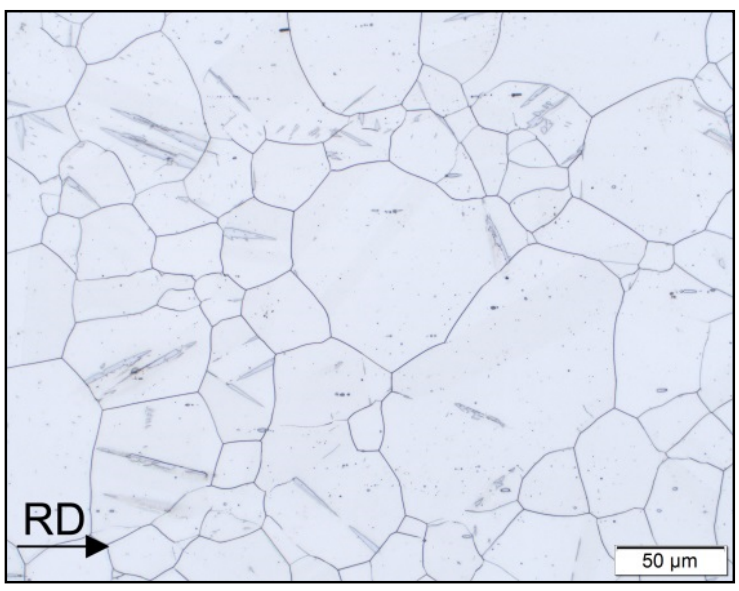

(b)

Figure 1. Microstructures of (a) the 3.5-mm hot-rolled strip and (b) the solution-annealed-1.8 mm cold-rolled strip. The arrows indicate the rolling direction (RD).

In addition to the average grain size of the austenite, Table 2 demonstrates the engineering stress strain properties and the fraction of deformation-induced $\alpha^{\prime}$ martensite $\left(\mathrm{V}_{\alpha^{\prime}}\right)$ after the tensile test. The $0.2 \%$ yield strength (YS) of the hot-rolled strip increased by approximately $100 \mathrm{MPa}$ compared to that of the annealed cold-rolled strip. The differences in the YS are mainly due to the different grain sizes of the austenite in the two microstructures. In accordance with the Hall-Petch relationship, where the YS is indirectly proportional to the square root of the grain size, higher tensile stresses must be generated in the fine-grained austenite to trigger plastic deformation [29,30]. As a consequence of more intensive $\alpha^{\prime}$ martensite formation, the annealed cold-rolled strip achieves a higher ultimate tensile strength (UTS) combined with a slightly lower uniform elongation (UE).

Table 2. Average grain size of austenite, mechanical properties, and deformation-induced $\alpha^{\prime}$ martensite fraction $\left(\mathrm{V}_{\alpha^{\prime}}\right)$ after tensile stress.

\begin{tabular}{|c|c|c|c|c|c|c|}
\hline Microstructure State & $\begin{array}{c}\text { Average } \\
\text { Grain Size } \\
{[\mu \mathrm{m}]}\end{array}$ & $\begin{array}{c}\text { ASTM } \\
\text { G } \\
{[-]}\end{array}$ & $\begin{array}{c}\text { YS } \\
\text { [MPa] }\end{array}$ & $\begin{array}{c}\text { UTS } \\
{[\mathrm{MPa}]}\end{array}$ & $\begin{array}{l}\text { UE } \\
{[\%]}\end{array}$ & $\begin{array}{l}\mathrm{V}_{\alpha^{\prime}} \\
{[\%]}\end{array}$ \\
\hline Hot-rolled strip & $9 \pm 5$ & 10 & 467 & 1102 & 40.0 & 68 \\
\hline Annealed cold-rolled strip & $36 \pm 23$ & 6 & 370 & 1171 & 38.5 & 75 \\
\hline
\end{tabular}


The flow curves of the two strips are shown in Figure 2a. The fine-grained austenite is characterized by a higher yield stress. In addition, both flow curves show inflection points typical for metastable austenitic steels with deformation-induced formation of $\alpha^{\prime}$ martensite. Talonen et al. and Hauser et al. showed for this steel group that the deformation-induced $\alpha^{\prime}$ martensite formation starts in the immediate vicinity before reaching the first inflection point and ends when the maximum tensile stress is reached [31,32]. To trigger the deformation-induced $\alpha^{\prime}$ martensite formation, a higher tensile stress must therefore be applied to the fine-grained hot-rolled strip than to the annealed coarse-grained strip. This means that not only the sliding as the carrier of the plastic deformation of the austenite but also the shearing of the austenite during the deformation-induced formation of $\alpha^{\prime}$ martensite is impeded in the fine-grained structure.

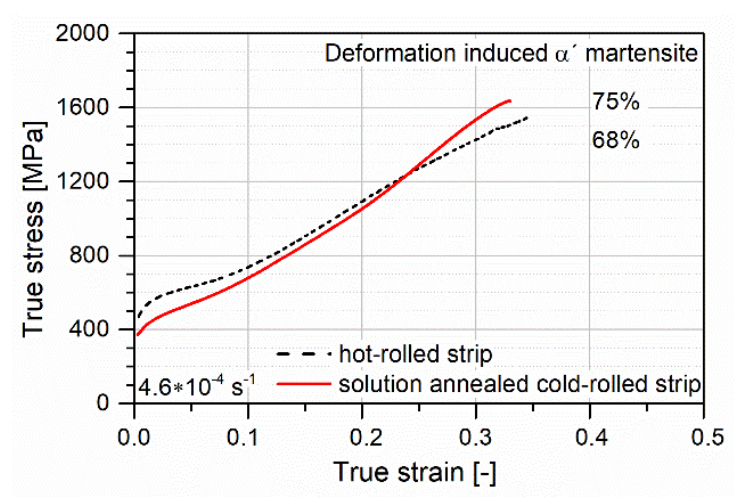

(a)

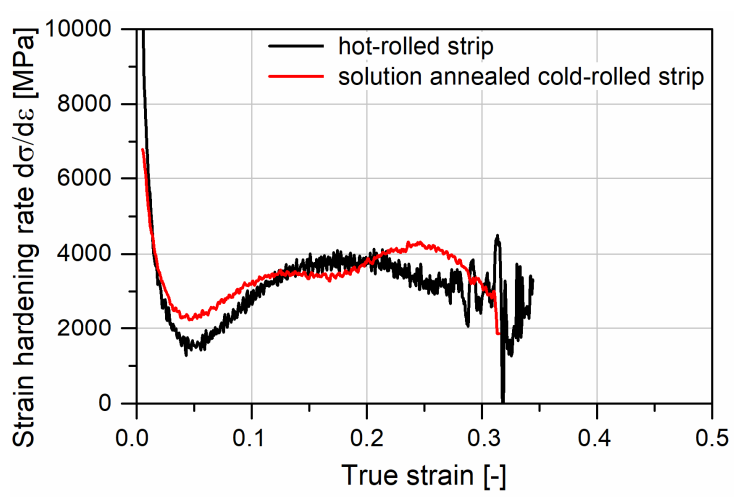

(b)

Figure 2. Mechanical properties of the hot-rolled strip and the cold-rolled strip; (a) Flow curve and (b) strain hardening rate.

This behavior also has an effect on the hardening of the steel during tensile loading. Figure $2 \mathrm{~b}$ shows the strain hardening rate, the increase of the flow curve, as a function of the true strain for the two austenitic microstructures. Both hardening curves have a minimum and a maximum corresponding to the first and second inflection point of the flow curves, respectively. The different hardening rates of the two austenite conditions are controlled by the respective fraction of deformation-induced $\alpha^{\prime}$ martensite. The more $\alpha^{\prime}$ martensite is produced, the higher the hardening rate. As a result, the formation of $\alpha^{\prime}$ martensite is less pronounced in the fine-grained hot-rolled strip than in the coarse-grained cold-rolled strip. This result is in good agreement with the investigations by Kisko et al. on the grain size influence on the deformation-induced $\alpha^{\prime}$ martensite formation of an austenitic stainless $\mathrm{Cr}-\mathrm{Mn}-\mathrm{Ni}-\mathrm{Cu}$ steel [33]. Jin et al. also concluded in investigations of a low-carbon austenitic alloy that grain refinement reduces deformation-induced martensite formation and stabilizes the austenite [30]. From the results, it is concluded that in coarser austenite, a higher fraction of $\alpha^{\prime}$ martensite is produced under load until material failure. This means that the deformation-induced $\alpha^{\prime}$ martensite formation is favored in the coarser austenite. The deformation processes of gliding and shearing overlap and interact with each other during the formation of the deformation-induced $\alpha^{\prime}$ martensite. The deformation-induced $\alpha^{\prime}$ martensite formation will stop when the glide capacity of the austenite is exhausted under external stress, as Weiß et al. have shown [8].

The results in Figure 2 show a special feature for the solution-annealed austenitic cold-rolled strip with respect to both the flow curve and the strain hardening rate. Deviating from the normal case, the flow curve does not have two but three inflection points. The true stress-strain curve of the annealed steel strip shows an almost linear increase at a true strain between 0.11 and 0.17 . This range is characterized by an almost constant work hardening rate. The discontinuity in the progression of work hardening also occurred in the investigations of Kisko et al. and is possibly due to the grain size inhomogeneity in the microstructures [33]. Figure $1 \mathrm{~b}$ shows small and large austenite grains placed 
side by side. In accordance with the above statements on the influence of the austenite grain size on martensite formation, it is concluded that the $\alpha^{\prime}$ martensite formation preferentially begins in the coarse austenite grains, whereas $\alpha^{\prime}$ martensite formation in the finer grains occurs at higher stresses. Above an elongation of 0.17 , work hardening continues to increase and reaches a maximum value greater than that of the hot-rolled strip. After the tensile test, $68 \mathrm{vol} \% \alpha^{\prime}$ martensite was formed in the hot-rolled strip, while $75 \mathrm{vol} \%$ austenite transformed to $\alpha^{\prime}$ martensite in the annealed cold-rolled strip.

\subsection{Microstructure and Mechanical Properties of Work-Hardened Cold-Rolled Strips}

Figure 3 shows the strip thickness and the fraction of $\alpha^{\prime}$ martensite as a function of the reduction rate of two cold rolling series with different cold rolling start temperatures. As the reduction rate increases and the thickness of the strips is reduced, the fraction of $\alpha^{\prime}$ martensite increases in both rolling series. The maximum reduction rates achieved were limited by the available maximum rolling force of the rolling mill. The strip thickness and the $\alpha^{\prime}$ martensite fraction formed differ in the two series depending on the rolling start temperature. In series 1 (Figure 3a), using a rolling temperature of $40^{\circ} \mathrm{C}$, five forming steps with a total degree of deformation of 0.85 can be carried out until the maximum rolling force is reached. The cold-rolled strip has a final thickness of $1.5 \mathrm{~mm}$ and contains $57 \mathrm{vol} \% \alpha^{\prime}$ martensite. In series 2 (Figure $3 b$ ), nine rolling steps with a total degree of deformation of approximately 1.3 can be carried out at rolling temperatures of 80 to $110^{\circ} \mathrm{C}$ from the second forming step onwards. The cold-rolled strip has a final thickness of $0.9 \mathrm{~mm}$ and an $\alpha^{\prime}$ martensite fraction of $37 \mathrm{vol} \%$. Due to the lower rolling start temperature, the formation of $\alpha^{\prime}$ martensite is more pronounced in the first series, which is accompanied by a stronger hardening of the cold-rolled strip. Therefore, the total degree of deformation is only 0.85 in the first series, while the degree of deformation in series 2 can be increased by approximately $53 \%$ using the same rolling force. The immense influence of the rolling temperature on the formation of deformation-induced $\alpha^{\prime}$ martensite was confirmed by repeated rolling tests in series 2. The reduction of the cold rolling temperature in rolling step 4 from 110 to $100{ }^{\circ} \mathrm{C}$ and in rolling steps 5 and 6 from 100 to $80^{\circ} \mathrm{C}$ (marked in the figure with deformation temperature (DT): $80^{\circ} \mathrm{C}$ ) leads to an increase of the $\alpha^{\prime}$ martensite fraction by approximately $27 \%$ to $47 \mathrm{vol} \%$. No cracks occurred during rolling. The strips therefore did not reach their maximum forming capacity.

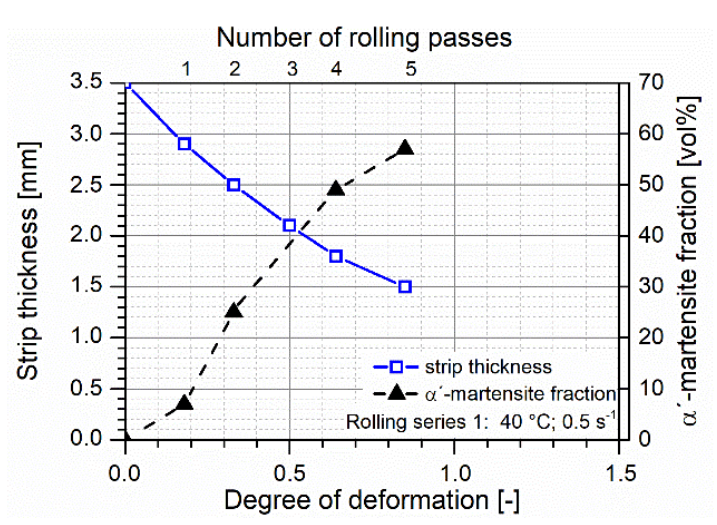

(a)

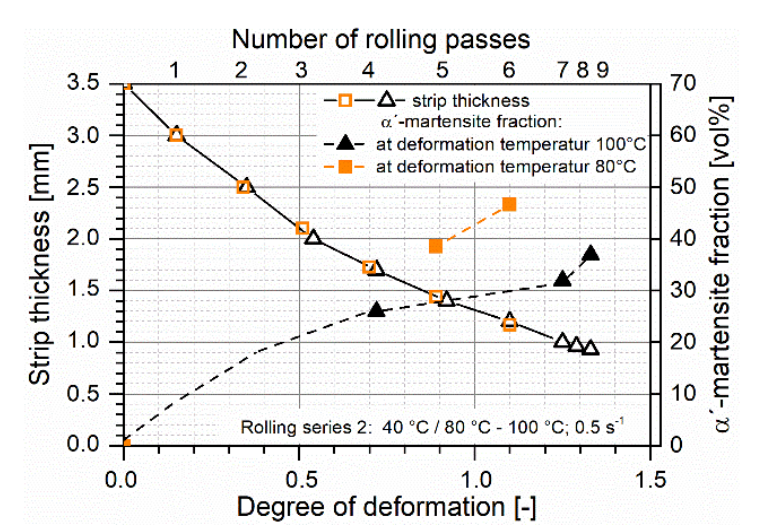

(b)

Figure 3. Strip thickness and deformation-induced $\alpha^{\prime}$ martensite fraction as a function of the degree of deformation or the number of roll passes of two cold rolling series; (a) Series 1: Rolling start temperature of $40{ }^{\circ} \mathrm{C}$ for all roll passes, (b) Series 2: Rolling start temperature of $40{ }^{\circ} \mathrm{C}$ in the initial roll pass and $80-100{ }^{\circ} \mathrm{C}$ in the further forming steps.

Figure 4 shows the mechanical properties and the deformation-induced martensite fractions in the dependence on the degree of deformation for the two rolling series. Thereby, Figure $4 \mathrm{a}$, d contain the $0.2 \%$-yield strengths and tensile strengths, including the desired tensile strength range for the spring steel strip (green). Figure $4 \mathrm{~b}$,e present the uniform elongation and total elongation (TE) and Figure $4 \mathrm{c}, \mathrm{f}$ show the deformation-induced $\alpha^{\prime}$ martensite fraction after the cold rolling passes and after 
subsequent tensile tests. Thus, the latter is the total fraction of the cold-rolling-induced $\alpha^{\prime}$ martensite and the $\alpha^{\prime}$ martensite formed during the tensile test. The $\alpha^{\prime}$ martensite decisively determines the mechanical properties. The increased $\alpha^{\prime}$ martensite formation due to the reduction of the rolling temperature is reflected in the higher $0.2 \%$-yield strength and ultimate tensile strengths and lower uniform elongations and total elongations.

a)

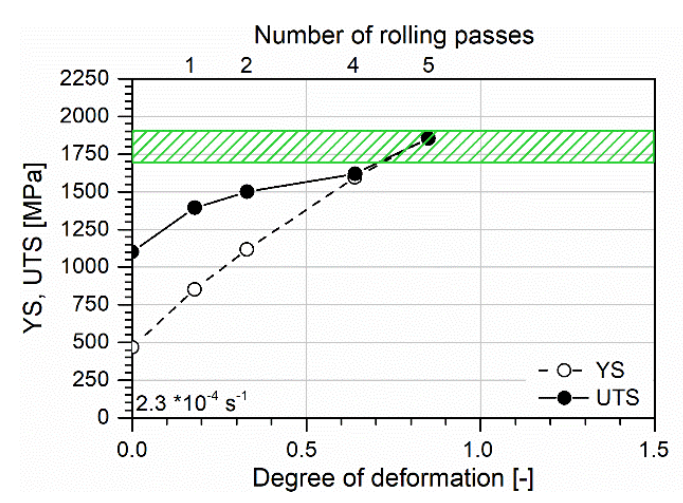

b)

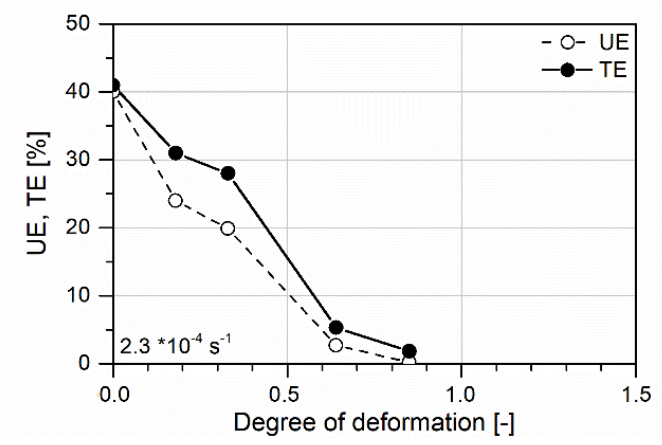

c)

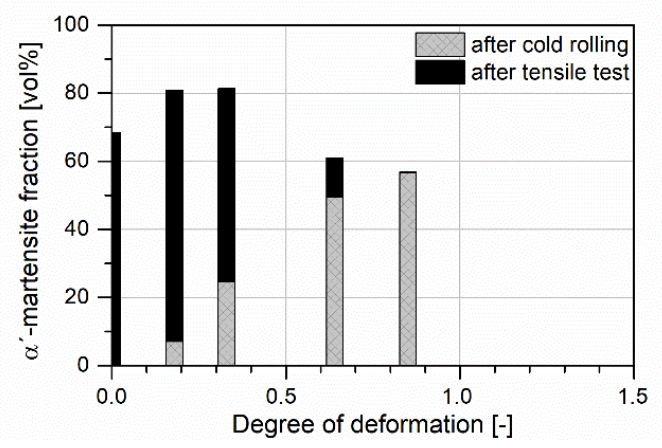

d)

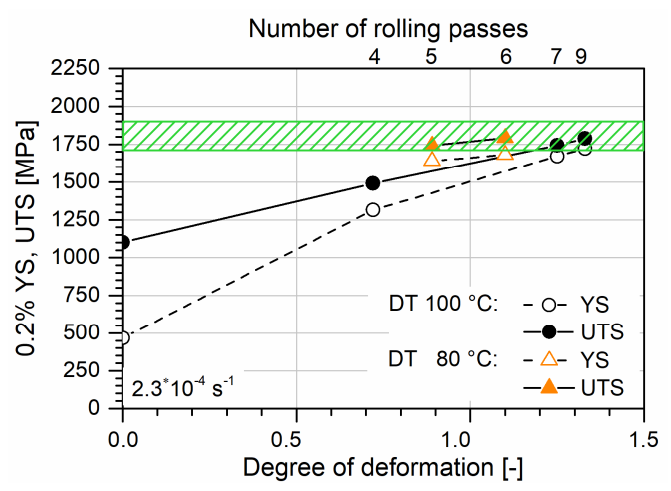

e)

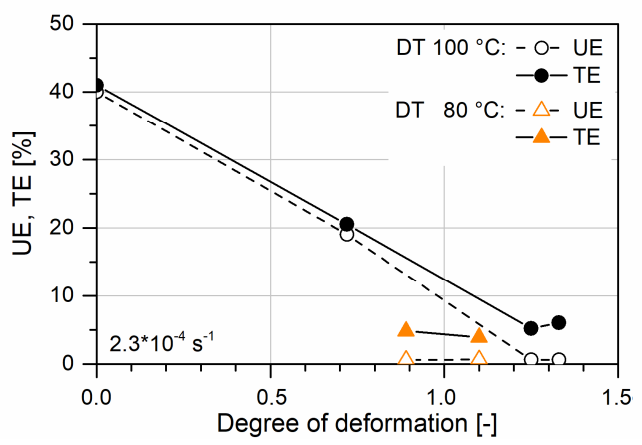

f)

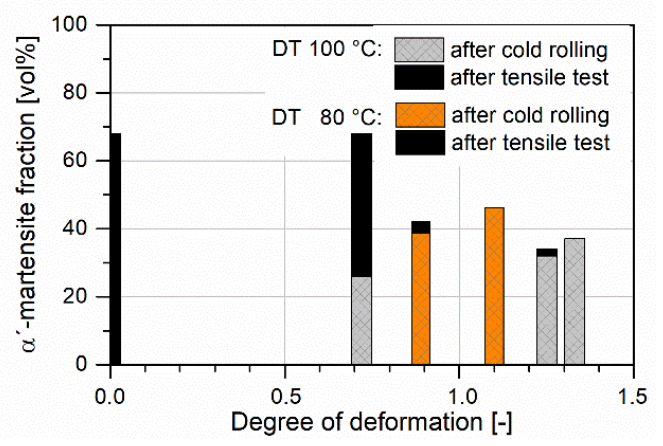

Figure 4. Mechanical properties and $\alpha^{\prime}$ martensite fractions of cold-rolled steel strip as a function of the degree of deformation for rolling series 1 and 2; $(\mathbf{a}, \mathbf{d})$ YS and UTS, $(\mathbf{b}, \mathbf{e})$ UE and TE, and $(\mathbf{c}, \mathbf{f}) \alpha^{\prime}$ martensite fraction in cold-rolled conditions and after tensile tests. The required tensile strength ranges for the spring steel strip $+\mathrm{C} 1700$ is marked with hatching.

The results in Figure 4a,d demonstrate that the yield strength increases to a greater extent than the tensile strength with an increasing degree of deformation and increasing $\alpha^{\prime}$ martensite fraction. As a result, the values converge and yield strength ratios of $>0.85$ are realizable. For rolling series 1 , the required minimum tensile strength of $1700 \mathrm{MPa}$ for the spring steel strip is narrowly missed with a degree of deformation of 0.64 and a $\alpha^{\prime}$ martensite fraction after rolling of $49 \mathrm{vol} \%$. In this work-hardened rolled condition, a further $12 \mathrm{vol} \% \alpha^{\prime}$ martensite is generated during the tensile test 
(Figure 4c). In rolling series 2, at higher rolling temperatures (DT) of 80 or $100^{\circ} \mathrm{C}$, degrees of deformation of 0.9 or 1.3 lead to an increase in the tensile strength in the desired range for the spring steel strip. Under these forming conditions, a high tensile strength is achieved despite lower fractions of martensite of 39 and $37 \mathrm{vol} \%$ respectively. In these steel strips, the austenite has already experienced an enormous work hardening during rolling. The increase in the dislocation density associated with cold forming stabilizes the austenite. Only the $2-3 \mathrm{vol} \%$ of austenite transforms into $\alpha^{\prime}$ martensite in the subsequent tensile test of the strips (Figure 4f). The transformation capacity of the austenite is thus almost exhausted. The maximum uniform elongation and total elongation decrease for both rolling series as the degree of deformation increases and the $\alpha^{\prime}$ martensite fraction increases, as shown in Figure $4 \mathrm{~b}, \mathrm{e}$ and Figure $4 \mathrm{c}, \mathrm{f}$. The total elongations are approximately $5 \%$ when the required tensile strength for the spring steel strip of $1700 \mathrm{MPa}$ is reached in both rolling series, despite significant differences in the $\alpha^{\prime}$ martensite fraction. Rolling series 1 results in a martensitic-austenitic microstructure, while rolling series 2 leaving a retained austenite fraction $>50 \%$ leads to an austenitic-martensitic microstructure.

The effects of a short-term heat treatment (D\&P) on the mechanical properties and especially on the tensile strength of the work-hardened steel strips are shown in the next section.

\subsection{Mechanical Properties of DEP-Treated Austenitic-Martensitic Cold-Rolled Strip}

The mechanical properties of cold-rolled spring steel strips are strongly affected by short-term tempering. Figure 5 shows, using the example of one work-hardened strip each from both rolling series, the strength and elongation parameters as well as the corresponding martensite fractions in the work-hardened state and after tempering below the reverse transformation temperature at 450 and at $500{ }^{\circ} \mathrm{C}$ and near to the reverse transformation temperature at $550^{\circ} \mathrm{C}$.

Rolling series 1

a)

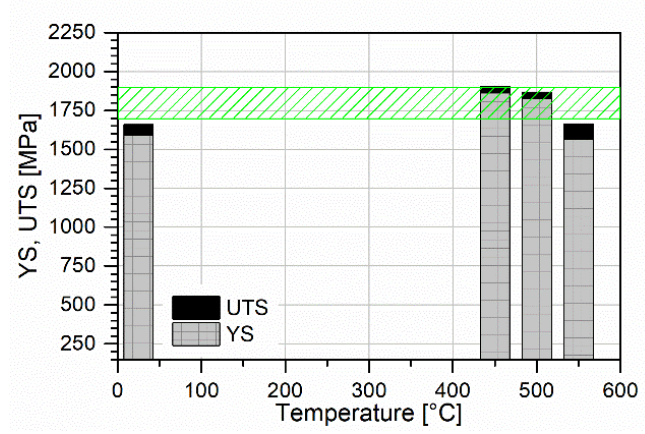

b)

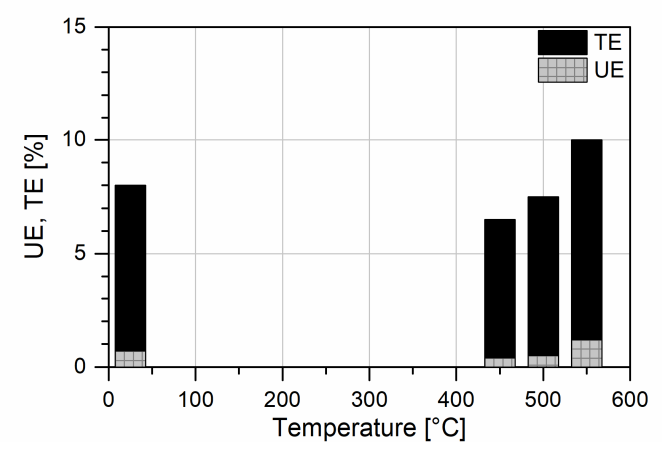

Rolling series 2

c)

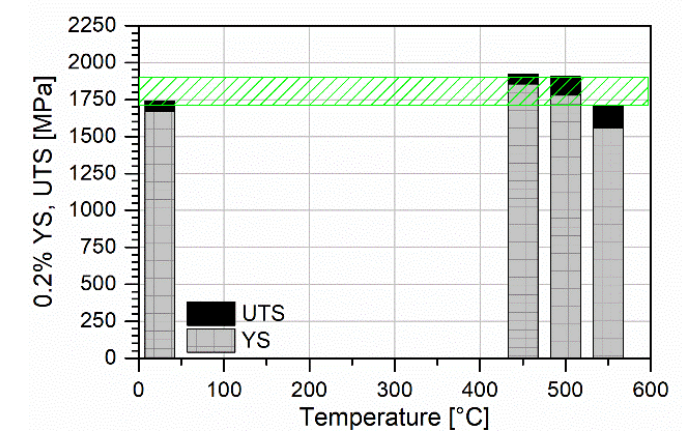

d)

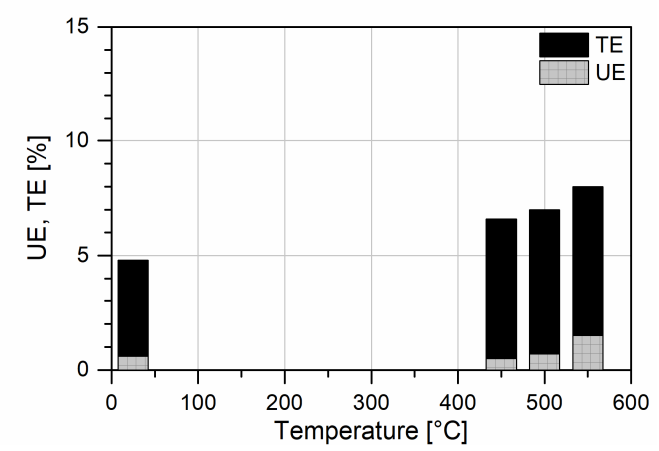

Figure 5. Mechanical properties of a cold-rolled strip in the work-hardened state and after tempering at 450,500 , and $550{ }^{\circ} \mathrm{C} ;(\mathbf{a}, \mathbf{b})$ rolling series 1 and $(\mathbf{c}, \mathbf{d})$ rolling series $2 ;(\mathbf{a}, \mathbf{c}) 0.2 \%$ YS, UTS; (b,d) UE, and TE. The required tensile strength ranges for the spring steel strip $+\mathrm{C} 1700$ are marked with hatching. 
The cold-rolled strips have ultimate tensile strengths of 1662 and $1740 \mathrm{MPa}$, respectively, in the initial state without partitioning treatment. While the degrees of deformation of cold-rolled steel strips differ significantly, at 0.66 and 1.0 respectively, and both strips have similar yield strengths and tensile strengths. However, they differ in their elongation behavior. The total elongation of the intensively cold-rolled strip is $40 \%$ lower than that of the cold-rolled strip of rolling series 1 due to the higher work hardening of the retained austenite. Both cold-rolled strips have an untypical microstructure for a spring strip with a predominant fraction of austenite. The austenite fraction is $52 \mathrm{vol} \%$ for rolling strategy 1 , whereas $62 \mathrm{vol} \%$ austenite is present for rolling strategy 2 .

The subsequent short-term tempering treatment of the cold-rolled strip in the temperature range of $450-550^{\circ} \mathrm{C}$ does not lead to any change in the martensite fraction. However, the tensile strength of both cold-rolled strips is significantly increased. The increase in strength reaches the highest level in both strips after tempering at $450{ }^{\circ} \mathrm{C}$. The tensile strengths of the heat treated cold-rolled strips are 1906 and $1923 \mathrm{MPa}$, respectively, for rolling series 1 and 2 . While according to rolling series 1 the increase in strength after heat treatment is $244 \mathrm{MPa}$ (approximately 15\%), for rolling series 2, a smaller increase of $181 \mathrm{MPa}$ (approximately 10\%) is observed. The strengthening due to D\&P treatment was more pronounced for the cold-rolled strip containing a higher martensite fraction. The tensile strength values in the cold strip decrease with an increasing tempering temperature. After tempering at $500{ }^{\circ} \mathrm{C}$, tensile strengths are achieved that are within the required strength range. At a tempering temperature of $550{ }^{\circ} \mathrm{C}$, the tensile strengths decrease below $1700 \mathrm{MPa}$ for the first series and to approximately $1700 \mathrm{MPa}$ for the second series.

Short-term tempering not only increases the tensile strength but can also have a positive effect on fracture elongation. In the cold-rolled strip from rolling series 2 with a lower $\alpha^{\prime}$ martensite fraction, higher total elongations are observed for all tempering temperatures compared to the work-hardened non-tempered condition. Such behavior only occurs in the cold-rolled strip with a higher $\alpha^{\prime}$ martensite fraction from rolling series 1 at annealing temperatures of $550{ }^{\circ} \mathrm{C}$. However, the cold-rolled strips of rolling series 1 reaches higher total elongations than the cold-rolled strips of series 2 both in the work-hardened condition and in the tempered condition. During the short-term tempering, the diffusion of the interstitial alloying elements $C$ and $N$ from the supersaturated $\alpha^{\prime}$ martensite is promoted. Nanocrystalline chromium-rich precipitates as described by Wendler et al. are apparently formed in the deformation-induced $\alpha^{\prime}$ martensite of the cold-rolled strip [34]. The experimental proof of these precipitates could not be provided so far in the studied steel. The strength-increasing effect of these precipitates likely depends on their coherence, type, size, number, and distribution.

A comparison of the results in Figures 4 and 5 show a surprising result regarding the mechanical properties of the cold-rolled strips of the novel spring steel. In the work-hardened cold-rolled strips with a predominant austenite content and tensile strengths just below $1700 \mathrm{MPa}$, it is possible to increase the required tensile strength to values above $1700 \mathrm{MPa}$ and even above $1900 \mathrm{MPa}$ by a 5-min short-term tempering at 450 and $500{ }^{\circ} \mathrm{C}$, respectively. In addition, such a cold-rolled strip is characterized by a relatively high total elongation of $\geq 6.5 \%$. The total elongation is far above the required $2 \%$ for a spring band. The D\&P-treated cold-rolled strip thus represents an alternative to conventional cold-rolled strips with a predominantly martensitic microstructure.

\section{Summary and Conclusions}

Appropriately cold-rolled as well as D\&P-treated cold-rolled strips of the austenitic steel X5CrMnNiMoN16-4-4 with a reduced nickel content in comparison to the conventional spring steel 1.4310 (X10CrNi18-8; AISI 301) are characterized by tensile strengths of 1700-1900 MPa and above. Due to the induced TRIP/TWIP effect and thus an increased plasticity during rolling, a high deformability can be achieved during cold rolling without intermediate annealing. The austenite grain size of the recrystallized hot and cold strip influences the deformation-induced $\alpha^{\prime}$ martensite formation in the subsequently work-hardened strips. A coarser austenite grain size leads to higher deformation-induced $\alpha^{\prime}$ martensite fractions. The tensile strength of the strips is mainly determined 
by the $\alpha^{\prime}$ martensite fraction and the work hardening of austenite. The increased formation of deformation-induced $\alpha^{\prime}$ martensite increases the hardening capacity of the strips. In addition, the formation of the deformation-induced $\alpha^{\prime}$ martensite depends on the applied deformation conditions and in particular on the deformation temperature. The lower the forming temperature during rolling, the more $\alpha^{\prime}$ martensite is produced. Such behavior was demonstrated using the example of two rolling routines with mainly different rolling temperatures. As the $\alpha^{\prime}$ martensite fraction increases, the $0.2 \%$ yield strengths increase more than the tensile strengths. This allows the realization of yield strength ratios of well over 0.85 . The maximum uniform and total elongation decrease are close to each other.

The tensile strength of the hardened cold-rolled strip was increased by a short tempering time of only $5 \mathrm{~min}$ in the temperature range from $450-500{ }^{\circ} \mathrm{C}$. Such a D\&P-treatment is particularly advantageous for work-hardened strips with predominantly austenitic microstructures whose tensile strengths are just below $1700 \mathrm{MPa}$. The increase in tensile strength due to the short-term tempering was found to be approximately 240 and $200 \mathrm{MPa}$, respectively. Due to the high fraction of austenite in the cold strip, relatively high total elongations of well over $2 \%$ were also present. The changes of the mechanical properties caused by the D\&P-treatment are assumed to be obviously caused by the nanocrystalline chromium-rich precipitates formed in $\alpha^{\prime}$ martensite. Their verification in the cold strip was not yet available. The results show that short-term tempering is a cost-effective alternative to conventional over 30-min tempering of cold strips.

Based on the existing mechanical properties of the developed austenitic steel X5CrMnNiMoN16-4-4, it is concluded that the steel can be considered as a novel stainless spring steel. The results show that the production of thinner spring strips with tensile strengths of 1700 to $1900 \mathrm{MPa}$, yield strength ratios of $>0.85$, yield strengths of $>1150 \mathrm{MPa}$, and total elongations of $>2 \%$ can be expected.

Author Contributions: As director of the Institute of Iron- and Steel Technology of the TU Bergakademie Freiberg, $\mathrm{O} . \mathrm{V}$. is responsible for the project management including the coordination of the planning and execution of research activities. A.W. and C.S. defined the goals of the project significantly and were able to win the Auerhammer Metallwerk $\mathrm{GmbH}$ as an industrial partner for the transfer project. Knowledge from earlier projects about the industrial production of austenitic stainless CrMnNiMoN-steel strip (BMBF 033R073B) implemented by A.W. and C.S. and from basic research about the development of stainless austenitic cast steels within the framework of the CRC 799 (M.W., O.V.) was used to develop the concept and to define the test methods. The published results were analysed and compiled by C.S. All authors have contributed to the publication of this article. All authors have read and agreed to the published version of the manuscript.

Funding: This research was funded by the Deutsche Forschungsgemeinschaft (DFG, German Research Foundation) within the framework of the Collaborative Research Center 799 (CRC 799), grant number 54473466.

Acknowledgments: We thank our partners in the transfer project, the Institute of Metal Forming and Auerhammer Metallwerk GmbH. Special thanks go to Mr. Michel for his project support and to the technical staff of the Institute of Iron and Steel Technology at the TU Bergakademie Freiberg.

Conflicts of Interest: The authors declare no conflict of interest.

\section{References}

1. Padilha, A.F.; Plaut, R.L.; Rios, P.R. Annealing of Cold-worked Austenitic Stainless Steels. ISIJ Int. 2003, 43, 135-143. [CrossRef]

2. Trillo, E.A.; Beltran, R.; Maldonado, J.G.; Romero, R.J.; Murr, L.E.; Fisher, W.W.; Advani, A.H. Combined Effects of Deformation (Strain and Strain State), Grain Size, and Carbon Content on Carbide Precipitation and Corrosion Sensitization in 304 Stainless Steel. Mater. Charact. 1995, 35, 99-112. [CrossRef]

3. Mola, J.; De Cooman, B.C. Quenching and Partitioning (Q\&P) Processing of Martensitic Stainless Steels. Metall. Mater. Trans. A 2013, 44, 946-967. [CrossRef]

4. Gümpel, P.; Ladwein, T.; Michel, E.; Strom, F.H. Wirksumme Loch- und Spaltkorrosion. TEW-Tech. Ber. 1988, 14, 12-25.

5. Nyström, M.; Lindstedt, U.; Karlsson, B.; Nilsson, J.-O. Influence of nitrogen and grain size on deformation behaviour of austenitic stainless steels. Mater. Sci. Technol. 1997, 7, 560-567. [CrossRef]

6. Degallaix, J.; Foct, J.; Hendry, A. Mechanical behaviour of high-nitrogen stainless steels. Mater. Sci. Technol. 1986, 2, 946-950. [CrossRef] 
7. Schröder, C.; Weiss, A.; Volkova, O. Development of a new stainless austenitic CrMnNi steel using TRIP/TWIP effect for a high cold formability. Mater. Werkst. 2018, 49, 577-590. [CrossRef]

8. Weiss, A.; Gutte, H.; Mola, J. Contributions of e and a'-TRIP Effects to the Strength and Ductility of AISI 304 (X5CrNi18-10) Austenitic Stainless Steel. Metall. Mater. Trans. A 2016, 47, 112-122. [CrossRef]

9. Jahn, A.; Kovalev, A.; Weiß, A.; Wolf, S.; Krüger, L.; Scheller, P.R. Temperature Depending Influence of the Martensite Formation on the Mechanical Properties of High-Alloyed Cr-Mn-Ni As-Cast Steels. Steel Res. Int. 2011, 82, 39-44. [CrossRef]

10. Wendler, M.; Weiss, A.; Krüger, L.; Mola, J.; Franke, A.; Kovalev, A.; Wolf, S. Effect of Manganese on Microstructure and Mechanical Properties of Cast High Alloyed CrMnNi-N Steels. Adv. Eng. Mater. 2013, 15, 558-565. [CrossRef]

11. Wendler, M. Metastabile Austenithaltige Cr-Mn-Ni-Stahlgusslegierungen mit C und N, Deren Erzeugung, Werkstoffverhalten und Festigkeitssteigerung. Ph.D Thesis, TU Bergakademie Freiberg, Freiberg, Germany, 2017.

12. Eichelmann, G.H.; Hull, F.C. The effect of composition on the temperature of spontaneous transformation of austenite to martensite in 18-8 type stainless steel. Trans. ASM 1953, 1953, 77-104.

13. Pickering, F.B. Physical Metallurgy and the Design of Steel; Applied Science Publishers: New York, NY, USA, 1978.

14. Schaeffler, A.L. Constitution diagram for stainless steel weld metal. Metall. Prog. 1949, 56, 680.

15. Weiss, A.; Gutte, H.; Radtke, M.; Scheller, P.R. Nichtrostender Austenitischer Stahlformguss, Verfahren zu dessen Herstellung und Seine Verwendung. Patent Document WO 2008/009722, 24 January 2008.

16. Schröder, C.; Wendler, M.; Kreschel, T.; Volkova, O.; Weiß, A. Development of a Stainless Austenitic Nitrogen-Alloyed CrMnNiMo Spring Steel. Crystals 2019, 9, 456. [CrossRef]

17. Nam, A.; Turdimatov, M.; Kawalla, R.; Prahl, U. The Kinetics of Dynamic Recrystallization of Fe-16Cr-xMn-4Ni-0.05C-0.17N Steel. Steel Res. Int. 2019, 90, 1800309. [CrossRef]

18. Nam, A.; Turdimatov, M.; Kawalla, R.; Prahl, U. Inter-Pass Softening Behavior of $\mathrm{Fe}-16 \mathrm{Cr}-\mathrm{x}$ Mn-4Ni-0.05C-0.17N Steel. Adv. Eng. Mater. 2019, 21, 1800692. [CrossRef]

19. Frehn, A.; Franke, A.; Bleck, W.; Weiss, A. Bedeutung der Umformtemperatur und -geschwindigkeit bei der Blechumformung austenitischer Stähle. UTF Sci. 2001, III, 8-12.

20. Weiss, A.; Lehnert, W.; Gutte, H.; Scheller, P.R. Verbesserung der Kaltumformbarkeit austenitischer CrNi-Stähle durch Nutzung des TRIP-Effektes. ATZ-Automob. Z. 2005, 1, 68-72. [CrossRef]

21. Schröder, C.; Weiss, A. Nichtrostender austenitischer CrMnNiMoN-Stahl mit TRIP/TWIP-Eigenschaften für Feinblech. In Freiberger Stahltag: 69. Berg- und Hüttenmännischer Tag 2018; Volkova, O., Ed.; Freiberger Forschungshefte; TU Bergakademie Freiberg: Freiberg, Germany, 2018; ISBN 978-3-86012-583-0.

22. Patel, J.R.; Cohen, M. Criterion for the action of applied stress in the martensitic transformation. Acta Metall. 1953, 1, 531-538. [CrossRef]

23. Müller-Bollenhagen, C. Verformungsinduzierte Martensitbildung bei Mehrstufiger Umformung und deren Nutzung zur Optimierung der HCF- und VHCF-Eigenschaften von Austenitischem Edelstahlblech. Ph.D. Thesis, TU Siegen, Siegen, Germany, 2011.

24. Berns, H.; Theisen, W. Eisenwerkstoffe - Stahl und Gusseisen; 4. bearb. Aufl.; Springer: Berlin, Germany, 2008; ISBN 978-3-540-79957-3.

25. Speer, J.; Matlock, D.K.; De Cooman, B.C.; Schroth, J.G. Carbon partitioning into austenite after martensite transformation. Acta Mater. 2003, 51, 2611-2622. [CrossRef]

26. Huang, Q.; De Cooman, B.C.; Biermann, H.; Mola, J. Influence of Martensite Fraction on the Stabilization of Austenite in Austenitic-Martensitic Stainless Steels. Metall. Mater. Trans. A 2016, 47, 1947-1959. [CrossRef]

27. Wendler, M.; Ullrich, C.; Hauser, M.; Krüger, L.; Volkova, O.; Weiss, A.; Mola, J. Quenching and partitioning (Q\&P) processing of fully austenitic stainless steels. Acta Mater. 2017, 133, 346-355. [CrossRef]

28. Dai, Q.-X.; Wang, A.-D.; Cheng, X.-N.; Luo, X.-M. Stacking fault energy of cryogenic austenitic steels. Chin. Phys. 2002, 596-600.

29. Belyakov, A.; Odnobokova, M.; Yanushkevich, Z.; Nazarova, M.; Kaibyshev, R. On strengthening of ultrafine grained austenitic steels subjected to large strain deformation. IOP Conf. Ser. Mater. Sci. Eng. 2019, 672, 012021. [CrossRef]

30. Jin, J.-E.; Jung, Y.-S.; Lee, Y.-K. Effect of grain size on the uniform ductility of a bulk ultrafine-grained alloy. Mater. Sci. Eng. A 2007, 449-451, 786-789. [CrossRef] 
31. Talonen, J.; Nenonen, P.; Pape, G.; Hänninen, H. Effect of strain rate on the strain-induced gamma to a'-martensite transformation and mechanical properties of austenitic stainless steels. Metall. Mater. Trans. A 2005, 36A, 421-432. [CrossRef]

32. Hauser, M.; Wendler, M.; Ghosh Chowdhury, S.; Weiss, A.; Mola, J. Quantification of deformation induced $\alpha^{\prime}$-martensite in $\mathrm{Fe}-19 \mathrm{Cr}-3 \mathrm{Mn}-4 \mathrm{Ni}-0.15 \mathrm{C}-0.15 \mathrm{~N}$ austenitic steel by in situ magnetic measurements. Mater. Sci. Technol. 2015, 31, 1473-1478. [CrossRef]

33. Kisko, A.; Misra, R.D.K.; Talonen, J.; Karjalainen, L.P. The influence of grain size on the strain-induced martensite formation in tensile straining of an austenitic $15 \mathrm{Cr}-9 \mathrm{Mn}-\mathrm{Ni}-\mathrm{Cu}$ stainless steel. Mater. Sci. Eng. A 2013, 578, 408-416. [CrossRef]

34. Wendler, M.; Hauser, M.; Motylenko, M.; Mola, J.; Krüger, L.; Volkova, O. Ultra High Strength Stainless Steels Obtained by Quenching-Deformation-Partitioning (QDP) Processing. Adv. Eng. Mater. 2019, 21, 1800571. [CrossRef]

(C) 2020 by the authors. Licensee MDPI, Basel, Switzerland. This article is an open access article distributed under the terms and conditions of the Creative Commons Attribution (CC BY) license (http://creativecommons.org/licenses/by/4.0/). 